\title{
STUDI KADAR TIMBAL (Pb) PADA TANAMAN KANGKUNG (Ipomea aquatik Forsk) DI SISI JALAN RAYA PURBAYASA KABUPATEN PURBALINGGA TAHUN 2016
}

\author{
Yuke Anggi Saptika'), Dwi Bayu Karti Utami' ${ }^{2}$ \\ Jurusan Kesehatan Lingkungan, Politeknik Kesehatan Kemenkes Semarang, \\ Jl. Raya Baturaden KM 12 Purwokerto, Indonesia
}

\begin{abstract}
Abstrak
$\mathrm{Pb}$ merupakan salah satu zat pencemar udara yang berasal dari sisa pembakaran kendaraan bermotor. Jumlah Pb yang ada di udara dapat mempengaruhi lingkungan di sekitarnya antara lain sayuran yang ditanam di pinggir jalan. Tujuan penelitian ini adalah untuk mengetahui kadar timbal $(\mathrm{Pb})$ pada tanaman kangkung, kepadatan kendaraan bermotor, kondisi lingkungan di sekitar lokasi penanaman kangkung dan pengelolaan tanaman kangkung di Sisi Jalan Raya Purbayasa Kabupaten Purbalingga tahun 2016. Metode penelitian yang digunakan bersifat deskriptif yaitu untuk mengetahui gambaran kadar timbal (Pb) pada tanaman kangkung, kepadatan kendaraan bermotor, kondisi lingkungan di sekitar lokasi penanaman kangkung dan pengelolaan tanaman kangkung di Sisi Jalan Raya Purbayasa Kabupaten Purbalingga tahun 2016. Hasil rata - rata yang diperoleh dari penelitian pada titik pertama yaitu sebesar 0,053 mg/kg bb dan titik kedua (KM 3) sebesar 0,032 mg/kg bb masih brada di bawah nilai ambang batas SNI 7387:2009 tentang batas maksimum cemaran logam berat berat pada pangan yaitu $0,5 \mathrm{mg} / \mathrm{kg}$. Kepadatan kendaraan di sekitar tempat tersebut yaitu arus stabil untuk sepeda motor dan bebas untuk mobil. Kondisi lingkungan termasuk berhawa sedang dan pengelolaan tanaman kangkung pada titik pertama menggunakan pestisida. Kesimpulan dan saran dari penelitian ini adalah kangkung yang ditanam di pinggir Jalan Raya Purbayasa sudah terpapar dengan timbal $(\mathrm{Pb})$ tetapi masih dibawah nilai ambang batas dan masih aman untuk dikonsumsi. Untuk para petani sebaiknya kurangi penggunaan pestisida, sebelum dimasak diicuci terlebih dahulu dibawah air mengalir, melakukan penghijauan lingkungan dengan penanaman pohon perindang di sepanjang jalan.
\end{abstract}

Kata kunci : Timbal, tanaman kangkung, di pinggir jalan

\begin{abstract}
Lead $(\mathrm{Pb})$ is one of the air pollutants that comes from residue of combustion of vehicles. The amount of $\mathrm{Pb}$ in the air may affect the surrounding environment, among the others are vegetables that grows on the roadside. The purpose of this study was to determine the level of lead $(\mathrm{Pb})$ in the plant kangkung, density of motor vehicles, environmental conditions around the site of kangkung plant and kangkung's crop management on Purbayasa Highway, Purbalingga regency 2016.The method used was descriptive to describe the levels of lead $(\mathrm{Pb})$ in the kangkung plant, density of motor vehicle, environmental conditions around the site of kangkung plant and kangkung crop management on Purbayasa Highway, Purbalingga regency 2016. The average results was obtained from research on the first point is equal to $0,053 \mathrm{mg} / \mathrm{kg} \mathrm{bw}$ and the second point (KM 3) of $0.032 \mathrm{mg} / \mathrm{kg} \mathrm{bw}$ still below the threshold value of ISO 7387: 2009 about the maximum limit metal contamination on food which is $0,5 \mathrm{mg} / \mathrm{kg}$. The density of vehicles in such areas are stable for motorcycle stream and free from cars. Environmental conditions are moderate temperature and kangkung crop management at the first point are found the use of pesticides. Conclusions and recommendations of this study is kangkung plant along Purbayasa Highway has been exposed to lead $(\mathrm{Pb})$, but still below the threshold value and are safe to eat. For farmers, they should reduce the use of pesticides, always wash before cook it under running water, greening the environment by planting trees along the road.
\end{abstract}

Keywords : Lead, Kangkung Plant, roadside.

\section{I.PENDAHULUAN}

Pembangunan kesehatan bertujuan untuk meningkatkan kesadaran, kemauan, dan kemampuan hidup sehat bagi masyarakat yang setinggi tingginya, sebagai investasi bagi pembangunan sumber daya manusia yang produktif secara sosial dan ekonomis (Undang undang Nomor 36 Tahun 2009). Kondisi lingkungan yang diharapkan dalam

1) Email : yukeanggie@gmail.com

2) Email : dwibayukartiutami@gmail.com pembangunan keseahatan adalah lingkungan yang kondusif bagi terwujudnya keadaan sehat yaitu lingkungan yang bebas dari polusi, tersedianya air bersih, sanitasi lingkungan yang baik, perumahan, pemukiman yang sehat, perencanaan kawasan yang berwawasan kesehatan, serta terwujudnya masyarakat yang saling tolong menolong dalam memelihara nilai - nilai budaya bangsa. 
Menurut Undang - undang RI No. 23 tahun 1997, Pencemaran Udara adalah masuk dan dimasukkannya makhluk hidup , zat, energi dan atau komponen lain ke dalam udara dan atau berubahnya tatanan (komposisi) udara oleh kegiatan manusia atau proses alam, sehingga kualitas udara turun sampai ke tingkat tertentu yang menyebabkan udara kurang atau tidak dapat berfungsi lagi sesuai dengan peruntukkannya.

Beberapa wilayah di Jakarta, seperti terminal bus dan daerah padat lalu lintas, memiliki udara dengan kadar logam berat $\mathrm{Pb}$ sekitar $2-8 \mathrm{mg} / \mathrm{m}^{3}$ udara. Asap kendaraan sebagai hasil dari pembakaran bahan bakar yang mengandung bahan tambahan (additive) $\mathrm{Pb}$ dapat menghasilkan emisi $\mathrm{Pb}$ organik. Logam $\mathrm{Pb}$ yang telah tercampur dengan bahan bakar kemudian akan bercampur dengan oli. Selanjutnya, melalui proses di dalam mesin kendaraan, logam $\mathrm{Pb}$ akan keluar dari knalpot bersama dengan gas buangan yang lainnya. Pencemaran dari emisi gas buangan kendaraan ini menyumbang sekitar 65\% dari pencemaran udara (Alsuhendra dan Ridawati, 2013, h.134).

Peningkatan pertumbuhan sektor transportasi dapat dilihat dan dirasakan pengaruhnya terhadap kehidupan manusia. Sejauh ini belum ada peraturan yang mengatur pembatasan laju produksi kendaraan bermotor, dan didukung sifat masyarakat Indonesia yang konsumsif, sehingga laju pertumbuhan kendaraan yang ada di Indonesia mencapai peningkatan yang nyata (Cahyadi, W., 2004 dalam Sri Rizqi, 2014).

Adanya kenyataan ini akan menimbulkan efek pencemaran udara yang serius dan salah satu bahan pencemaran udara yang berbahaya adalah adanya paparan logam berat Plumbum (Pb) atau lebih dikenal dengan nama Timah Hitam atau Timbal.

Timah hitam atau Pb merupakan sisa - sisa pembakaran yang terjadi antara bahan bakar dengan mesin kendaraan. Melalui buangan mesin kendaraan tersebut unsur $\mathrm{Pb}$ terlepas ke udara. Sebagian diantaranya akan membentuk partikulat di udara bebas dengan unsur - unsur lain, sedangkan sebagian lainnya akan akan menempel dan diserap oleh tumbuh - tumbuhan yang ada di sepanjang jalan (Heryando Palar, 2008, h.40).

Sayuran air termasuk tanaman yang mudah tumbuh pada lingkungan tercemar. Akibatnya, apabila terjadi pencemaran logam berat pada lingkungan , maka logam berat tersebut akan diserap melalui akar dan stomata daun dan selanjutnya terserap ke dalam jaringan tanaman. Jika makanan tersebut dimakan oleh makhluk hidup lain, termasuk manusia, maka terjadilah proses penumpukan atau biomagnifikasi melalui siklus rantai makanan. Logam berat yang terakumulasi di dalam jaringan tubuh akan menimbulkan keracunan bagi hewan atau manusia jika telah melebihi batas toleransi (Alsuhendra dan Ridawati, 2013, h.135).
Sayuran yang ditanam di pinggir jalan atau dekat dengan jalan raya dan rentan polusi udara mengandung logam berat dalam jumlah tinggi. Sebuah penelitian menunjukkan bahwa kandungan $\mathrm{Pb}$ dalam sayuran tersebut cukup tinggi, yaitu sekitar 28,78 ppm (Alsuhendra dan Ridawati, 2013, h.135).

Penelitian lain yang dilakukan Ayu (2002) memperlihatkan bahwa kangkung dan bayam yang dijual di pasar - pasar wilayah Bogor mengandung $\mathrm{Pb}$ antara $<0,01-3,12$ ppm pada kangkung dan < 0.01 - 3.38 ppm pada bayam. Dinyatakan bahwa jalur distribusi dan cara pengangkutan sangat berpengaruh terhadap bertambahnya kadar $\mathrm{Pb}$ karena ada tambahan pencemaran $\mathrm{Pb}$ dari emisi gas buangan kendaraan bermotor selama proses distribusi (Alsuhendra dan Ridawati, 2013, h.135).

\section{II.BAHAN DAN METODE}

Penelitian ini dilaksanakan di Desa Purbayasa Kecamatan Padamara Kabupaten Purbalingga dengan luas wilayah Desa Purbayasa 94.998 ha dengan ketinggian 1000m diatas permukaan laut (Sumber : BPS Kabupaten Purbalingga, Hasil Proyeksi Penduduk Tahun 2015). Sampel yang digunakan adalah tanaman kangkung yang diambil dari 2 lokasi, masing - masing lokasi diambil sebanyak 3 sampel sehingga jumlah sampel yang diperiksa adalah 6 . Jenis penelitian ini adalah deskriptif, peneliti hanya mendeskripsikan kadar timbal pada kangkung, mengukur kepadatan kendaraan bermotor, mendeskripsikan lingkungan sekitar penanaman kangkung dan pengelolaan tanaman kangkung.

Sampel dalam penelitian adalah tanaman kangkung segar yang ditanam di sisi Jalan Raya Purbayasa. Jumlah sampel yang digunakan adalah sebanyak 6 sampel, Cara pengumpulan data yaitu berupa :

1. Pemeriksaan kadar timbal di laboratorium dengan menggunakan metode AAS

2. Wawancara terhadap petani kangkung di Desa Purbayasa

3. Penghitungan kepadatan kendaraan bermotor yang melintas di sisi lokasi pengambilan sampel

4. Dokumentasi yaitu untuk mendapatkan data sekunder berupa data umum mengenai Kecamatan Padasmara dan data curah hujan melalui Badan Pusat Statistik Kabupaten Purbalingga

\section{III.HASIL DAN PEMBAHASAN}

\section{Hasil}

Lokasi penelitian adalah Jalan Raya Purbayasa Kecamatan Padamara Kabupaten Purbalingga dengan luas wilayah Desa Purbayasa adalah 94,998 ha yang berbatasan langsung dengan Desa Karang Gambas di sebelah Utara, Desa Padamara di sebelah Selatan, Desa Prigi di sebelah Timur dan Desa Kalitinggar di Sebelah Barat (Sumber : Monografi Desa Purbayasa). Desa Purbayasa terletak di ketinggian 1000m di atas 
permukaan laut dengan curah hujan berkisar antara $3.938 \mathrm{~mm} /$ tahun. Suhu rata - rata di wilayah tersebut adalah $28-30^{\circ} \mathrm{C}$ dan kelembaban rata - rata sebesar 51\% (Sumber : BPS Kabupaten Purbalingga, Hasil Proyeksi Penduduk Tahun 2015).

Jalan Raya Purbayasa merupakan tempat yang ramai oleh aktivitas masyarakat, salah satunya aktivitas kendaraan bermotor, mobil dan sejenisnya memiliki panjang $6 \mathrm{~km}$ dan lebar 10m. Kondisi jalan yang digunakan sebagai penghubung di Desa Purbayasa sudah menggunakan aspal dengan tipe jalan adalah 2 lajur 2 arah tanpa pembatas median.

1. Gambaran Umum Petani Kangkung di Jalan Raya Purbayasa Desa Purbayasa

Penelitian kadar Timbal $(\mathrm{Pb})$ pada tanaman kangkung dilakukan dengan cara pembelian sampel pada petani kangkung di sepanjang Jalan Raya Purbayasa. Jumlah petani kangkung yang ditemukan di Jalan Raya Purbayasa hanya 2 petani, sehingga peneliti melakukan pengambilan sampel pada 2 petani tersebut. Adapun data yang telah diperoleh antara lain :

Tabel 4.1 Nama, jenis kelamin, pendidikan dan jenis sampel petani kangkung di Jalan Raya Purbayasa

\begin{tabular}{cccccc}
\hline No Nama & $\begin{array}{c}\text { Jenis } \\
\text { Kelamin }\end{array}$ & Umur Pendidikan & $\begin{array}{c}\text { Jenis } \\
\text { Sampel }\end{array}$ \\
\hline 1 & SN & Laki - laki & 75 & SMA & Kangkung \\
\hline 2 & RT & Perempuan & 70 & SD & \\
\hline \multicolumn{5}{c}{ Sumber : Hasil Penellitian } &
\end{tabular}

2. Hasil Pemeriksaan Kadar Timbal (Pb) Pada Kangkung

Hasil pemeriksaan kadar Timbal (Pb) dengan menggunakan alat Spektrofotometer Absorpsi Atom (AAS) pada kangkung yang ditanam di sisi Jalan Raya Purbayasa, didapatkan hasil rata - rata sebagai berikut:

Tabel 4.2 Hasil pemeriksaan Kadar Timbal (Pb) pada kangkung Di Jalan Raya Purbayasa Desa Purbayasa

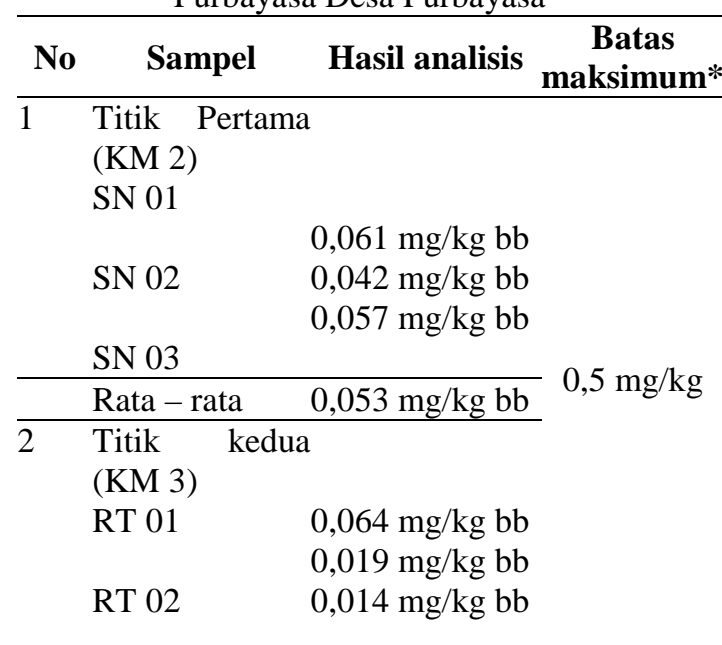

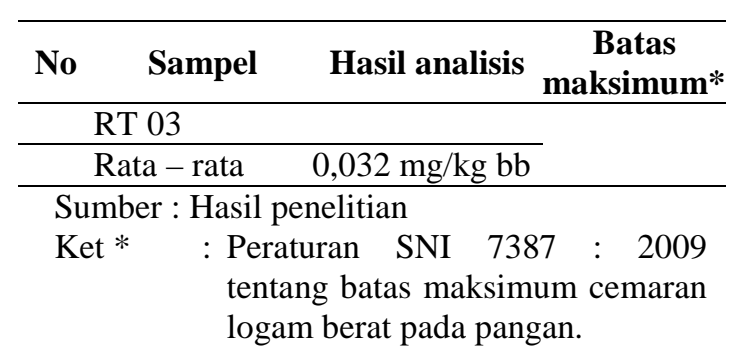

3. Kepadatan Kendaraan.

Tingkat kepadatan kendaraan yang melintas dapat diketahui dengan menggunakan rumus $\frac{V J P}{C}$. Adapun hasil rekapitulasi perhitungan tingkat kepadatan kendaraan di lokasi penelitian adalah sebagai berikut :

Tabel 4.3 Kepadatan kendaraan yang melintas di Jalan Raya Purbayasa

\begin{tabular}{|c|c|c|c|c|}
\hline \multirow{2}{*}{ Lokasi } & \multicolumn{2}{|c|}{$\begin{array}{c}\text { Lalu lintas harian } \\
\text { rata - rata }\end{array}$} & \multicolumn{2}{|c|}{$\begin{array}{l}\text { V/C ratio } \\
\text { (smp/jam) }\end{array}$} \\
\hline & $\begin{array}{c}\text { Sepeda } \\
\text { motor }\end{array}$ & Mobil & $\begin{array}{c}\text { Sepeda } \\
\text { motor }\end{array}$ & Mobil \\
\hline $\begin{array}{l}\text { Titik } \\
\text { pertama } \\
\text { (KM 2) }\end{array}$ & $\begin{array}{c}1630 \\
\text { smp/jam }\end{array}$ & $\begin{array}{c}10 \\
\text { smp/jam }\end{array}$ & 0,63 & 0,0038 \\
\hline $\begin{array}{l}\text { Titik Kedua } \\
\text { (KM 3) }\end{array}$ & $\begin{array}{c}1502 \\
\text { smp/jam }\end{array}$ & 9 smp/jam & 0,58 & 0,0034 \\
\hline $\begin{array}{l}\text { Sumber } \\
\text { Keterangan }\end{array}$ & $\begin{array}{ll}: & \text { Hasil p } \\
: & \text { smp/jal } \\
& \text { penum }\end{array}$ & $\begin{array}{l}\text { enelitian } \\
\text { m (sa } \\
\text { pang/jam) }\end{array}$ & & mobil \\
\hline
\end{tabular}

Volume / Kapasitas (V/C ratio)

Titik pertama (KM 2)

- Sepeda motor

$$
\begin{aligned}
& : \quad \frac{V J P}{C}=\frac{1630}{2572}=0,63 \\
& : \quad \frac{V J P}{C}=\frac{10}{2572}=0,0038
\end{aligned}
$$
smp/jam

(arus stabil)

- Mobil smp/jam

(Arus bebas)

Titik kedua (KM 3)

- $\quad$ Sepeda motor

$$
\begin{aligned}
& : \quad \frac{V J P}{C}=\frac{1502}{2572}=0,58 \\
& : \quad \frac{V J P}{C}=\frac{9}{2572}=0,0034
\end{aligned}
$$
smp/jam

(Arus stabil)

- Mobil

smp/jam

(Arus bebas)

Berdasarkan hasil pengamatan selama 1 jam di dua titik diperoleh dengan hasil kriteria arus stabil untuk sepeda motor dan arus bebas untuk mobil. Arus stabil merupakan volume lalu lintas sedang dan kecepatan mulai dibatasi oleh kondisi lalu lintas sedangkan arus bebas merupakan volume lalu lintas rendah dan kecepatan tinggi.

4. Kondisi Lingkungan Pada Saat Pengambilan Sampel 
Pengambilan sampel dilaksanakan pada hari Minggu tanggal 27 Maret 2016 pukul 07.00 WIB dengan kondisi lingkungan sperti temperatur udara $28^{\circ} \mathrm{C}$, kelembaban udara $60 \%$, dan arah angin menuju ke utara.

5. Pengelolaan Tanaman Kangkung

Petani kangkung di Jalan Raya Purbayasa pada titik pertama (KM 2) melakukan pemberantasan hama dengan nama dagang buldog, pemberantasan dilakukan setiap 2 minggu sekali. Petani biasanya akan menyemprotkan pestisida pada pagi hari. Petani pada titik kedua (KM 3) tidak melakukan pemberantasan hama (tidak menggunakan pestisida jenis apapun). Setiap 2 hari sekali rumput - rumput yang tumbuh di sekitar tanaman kangkung akan dibersihkan. Kangkung yang berada di titik pertama berumur 9 bulan sementara untuk titik kedua berumur 6 bulan. Pada saat pengambilan sampel pada titik pertama (KM 2) kangkung berumur 14 hari dan pada titik kedua (KM 3) kangkung berumur 15 hari setalah pemanenan terakhir. Apabila umur kangkung sudah mencapai satu tahun lebih maka kangkung akan dibuang dan diganti dengan bibit yang baru. Pemanenan kangkung akan dilakukan satu bulan setelah penanaman dengan bibit yang baru, kemudian setiap $14-21$ hari sudah dapat dipanen.

\section{Pembahasan}

1. Pemeriksaan Kadar Timbal

Hasil dari tabel 4.2 dapat diketahui bahwa sampel kangkung yang diperiksa mengandung Timbal (Pb). Hasil rata-rata pemeriksaan kadar timbal pada kangkung di titik pertama (KM 2) didapatkan hasil sebesar 0,053 $\mathrm{mg} / \mathrm{kg}$ bb dan pada titik kedua (KM 3) didapatkan hasil sebesar $0,032 \mathrm{mg} / \mathrm{kg}$ bb. Secara umum hasil rata - rata pemeriksaan kadar Timbal (Pb) pada tanaman kangkung masih di bawah nilai ambang batas, berdasarkan peraturan SNI 7387: 2009 tentang batas maksimum cemaran logam berat pada pangan yaitu kelompok buah dan sayur serta hasil olahannya batas maksimumnya adalah sebesar 0,5 mg/kg.

Meskipun masih aman dikonsumsi tetapi jika sering memakan makanan tersebut, maka Timbal (Pb) akan terakumulasi pada tubuh. Menurut Alsuhendra dan Ridawati (2013, 147148) apabila asupan $\mathrm{Pb}$ seseorang sekitar 2,5 mg/hari, maka waktu yang diperlukan untuk menujukkan efek toksik dari $\mathrm{Pb}$ adalah sekitar 4 tahun, assupan $\mathrm{Pb}$ sekitar 3,5 mg/hari, maka efek toksik akan terlihat dalam beberapa bulan saja.

Selain melalui pernapasan, logam $\mathrm{Pb}$ dapat masuk ke dalam tubuh melalui saluran pencernaan. Pada orang dewasa, sekitar 5 - 19\% $\mathrm{Pb}$ diserap melalui usus. Tingkat penyerapan ini bergantung pada berbagai faktor yang mempengaruhi, antara lain adalah puasa. Dalam keadaan puasa, penyerapan $\mathrm{Pb}$ dari usus lebih besar dibandingkan dengan keadaan normal, yaitu sekitar $15-20 \%$. Selain puasa umur juga mempengaruhi tingkat penyerapan $\mathrm{Pb}$ pada makanan. Anak - anak mampu menyerap jumlah $\mathrm{Pb}$ lebih banyak daripada orang dewasa. Bahkan anak - anak yang berumur 3-8 tahun dapat menyerap Pb hingga 50\%.

Janin dalam kandungan, bayi dan anak- anak lebih sensitif terhadap paparan $\mathrm{Pb}$ karena $\mathrm{Pb}$ lebih mudah diserap pada tubuh yang sedang berkembang. Jaringan otot anak - anak lebih sensitif daripada orang dewasa. Setelah beberapa minggu, sekitar 99\% $\mathrm{Pb}$ yang masuk ke dalam tubuh orang dewasa dapat diekskresikan. Sementara itu, pada anak - anak hanya 32\% yang dapat diekresikan. Karena $\mathrm{Pb}$ larut dalam air $\mathrm{Pb}$ diekskresikan terutama melalui urine. Hal ini terjadi apabila kandungan $\mathrm{Pb}$ dalam plasma dan di dalam urine terlihat proporsional. Selain itu, $\mathrm{Pb}$ juga diekskresikan melalui fases, keringat, dan ASI. Logam Pb dapat didepositkan di dalam rambut dan kuku. Biasanya tubuh mengekskresikan $\mathrm{Pb}$ dalam jumlah sangat kecil, meskipun asupan $\mathrm{Pb}$ setiap hari meningkat. Dengan keadaan demikian, kandungan $\mathrm{Pb}$ dalam tubuh terus bertambah.

Setelah masuk dalam tubuh, $\mathrm{Pb}$ diperlakukan seperti halnya logam kalsium (Ca). Logam $\mathrm{Pb}$ pertama kali diserap di plasma dan membran jaringan lunak. Kemudian $\mathrm{Pb}$ didistribusikan ke gigi pada anak - anak, dan tulang pada semua umur. Setelah diserap oleh usus, $\mathrm{Pb}$ didistribusikan ke dalam jaringan melalui darah. Ada 3 lokasi atau jaringan utama di mana $\mathrm{Pb}$ dapat dideteksi di dalam tubuh, antara lain adalah sebagai berikut :

a. Sel Darah Merah

Logam $\mathrm{Pb}$ terikat dalam sel darah merah (eritrosit) dengan waktu paruh sekitar 25 30 hari.

b. Jaringan lunak, seperti hati, otak dan ginjal Sebagian kecil $\mathrm{Pb}$ disimpan di dalam otak. Waktu paruh $\mathrm{Pb}$ di dalam jaringan lunak adalah sekitar beberapa bulan.

c. Tulang dan jaringan - jaringan keras, seperti gigi dan tulang rawan

Sekitar 90-95\% Pb di dalam tubuh terdapat dalam tulang dengan bentuk Pb-fosfat $\left(\mathrm{Pb}_{3}\left(\mathrm{PO}_{4}\right)_{2}\right)$. Waktu paruhnya mencapai 30 40 tahun.

Menurut Alsuhendra dan Ridawati (2013, h.149-150) Gangguan yang ditimbulkan $\mathrm{Pb}$ terhadap kesehatan adalah :

a. Anemia, melalui mekanisme :

1) Penghambatan enzim hemesintetase. Logam $\mathrm{Pb}$ akan menghambat enzim hemesintetase, yang mengakibatkan penurunan produksi heme. 
2) Peningkatan protoprofirin. Perubahan protoporfirin IX menjadi heme akan terhambat dengan adanya $\mathrm{Pb}$ dan menyebabkan terjadinya akumulasi protoporfirin IX yang dapat diketahui pada plasma dan feses.

3) Peningkatan koproporfirin. Akumulasi dari protoprofirin akan meningkatkan akumulasi koproprofirin III yang dapat diketahui dari kadar koproprofirin III pada urine dan feses.

b. Efek terhadap syaraf (sistem syaraf pusat)

c. Encephalopathy, yaitu sindrom gejala neurologis yang berat dan dapat berakhir dengan kerusakan otak atau kematian

d. Gangguan pendengaran

e. Efek terhadap ginjal. Keracunan Pb kronis akan menyebabkan penyakit renalprogresif dan tidak dapat disembuhkan.

f. Efek terhadap sistem reproduksi. Keracunan $\mathrm{Pb}$ dapat menyebabkan gangguan reproduksi, baik pada perempuan maupun pada laki - laki. Logam $\mathrm{Pb}$ dapat menembus jaringan plasenta, sehingga menyebabkan kelainan pada janin. Kadar $\mathrm{Pb}$ darah ibu hamil dalam jumlah tertentu dapat mengakibatkan kelainan yang berbeda, yaitu:

1) Kadar $\mathrm{Pb}$ darah $10 \mu \mathrm{g} / \mathrm{dl}$ dapat mengakibatkan gangguan pertumbuhan

2) Kadar $\mathrm{Pb}$ darah $30 \mu \mathrm{g} / \mathrm{dl}$ dapat mengakibatkan kelainan prematur

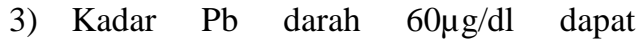
mengakibatkan komplikasi kehamilan.

Pengobatan dan Pencegahan Keracunan

Timbal menurut F.G. Winarno dan Titi Sulistyowati Rahayu (1994, h.158) adalah :

a. Pengobatan

Pengobatan yang dilakukan oleh dokter adalah dengan pemberian obat yang dikenal sebagai chelating agents yaitu suatu senyawa yang mampu mengikat timbal dalam darah dan menariknya keluar tubuh melalui urine.

Teknik pengobatan ini memiliki beberapa kelemahan, diantaranya adalah karena obat obat tersebut tergolong berbahaya dan tidak selalu tepat digunakan bagi anak - anak, jenis obat obat tersebut tidak berdaya dalam memperbaiki otak yang sudah terlanjur rusak akibat keracunan timbal.

b. Pencegahan

1) Menghidari konsumsi jenis makanan sumber timbal, seperti kerang kerangan dan jeroan.

2) Memilih makanan kaleng yang dilas pada sambungannya karena makanan kaleng yang masih dipatri sambungannya merupakan sumber timbal yang besar.
3) Sebaiknya untuk para ibu muda yang sedang mengandung untuk menghindari mengkonsumsi Bone meal tablet (yang digunakan sebagai suplemen kalsium dan phospat) karena sering tinggi kandungan timbalnya terutama yang berasal dari tulang ternak.

2. Kepadatan Kendaraan

Berdasarkan tabel 4.3 diperoleh hasil titik pertama (KM 2) terdiri dari 1630 smp/jam sepeda motor dan $10 \mathrm{smp} / \mathrm{jam}$ mobil, dengan volume /kapasitas (V/C ratio) sebesar 0,63 untuk motor dan 0,0038 untuk mobil. Sedangkan titik kedua (KM 3) untuk sepeda motor 1520 smp/jam dan $9 \mathrm{smp} / \mathrm{jam}$ mobil, dengan volume/kapasitas (V/C Ratio) sebesar 0,58 untuk motor dan 0,0034 untuk mobil. Dengam melihat volume/kapasitas kedua titik tersebut termasuk dalam kriteria arus stabil pada sepeda motor dan arus bebas pada mobil. Adapun pejelasan dari kondisi arus bebas dan arus stabil adalah sebagai berikut :

a Arus bebas

1) Arus bebas dengan volume lalu lintas rendah dan kecepatan tinggi, rata - rata $\geq 80 \mathrm{~km} / \mathrm{jam}$.

2) Kepadatan lalu lintas sangat rendah dengan kecepatan yang dapat dikendalikan oleh pengemudi berdasarkan batasan kecepatan maksimum/ minimum dan kondisi fisik jalan.

3) Pengemudi dapat mempertahankan kecepatan yang diinginkannya tanda atau dengan sedikit tundaan.

b Arus Stabil

1) Arus stabil dengan volume lalu lintas sedang dan kecepatan mulai dibatasi oleh kondisi lalu lintas, rata - rata kecepatan $\geq 40 \mathrm{~km} / \mathrm{jam}$.

2) Kepadatan lalu lintas rendah, hambatan internal lalu lintas belum mempengaruhi kecepatan.

3) Pengemudi masih punya cukup kebebasan untuk memilih kecepatannya dan lajur jalan yang digunakan.

Dari kedua titik tersebut yang paling banyak kendaraan melintas adalah pada titik pertama (KM 2). Kadar Timbal (Pb) pada titik pertama (KM 2) lebih besar dibandingkan pada titik kedua (KM 3). Dengan demikian permasalahan yang muncul dari hasil tersebut yaitu banyaknya kendaraan yang melintasi pada titik pertama (KM 2.

Menurut Heryando Palar (2004, h.78-79) Emisi $\mathrm{Pb}$ ke dalam lapisan atmosfir bumi dapat berbentuk partikulat dan gas. Emisi $\mathrm{Pb}$ yang masuk dalam bentuk gas, terutama sekali berasal dari buangan gas kendaraan bermotor. Emisi tersebut merupakan hasil samping dari pembakaran yang terjadi dalam mesin - mesin 
kendaraan. $\mathrm{Pb}$ yang merupakan hasil samping dari pembakaran ini berasal dari senyawa tetrametil-Pb dan tetraetil-Pb yang selalu ditambahkan dalam bahan bakar kendaraan bermotor dan berfungsi sebagai anti ketuk (anti knock) pada mesin - mesin kendaraan.

Disamping itu dalam bahan bakar kendaraan bermotor biasanya ditambahkan pula bahan scavenger, yaitu etilondibromida $\left(\mathrm{C}_{2} \mathrm{H}_{4} \mathrm{Br}_{2}\right)$ dan etilendikhlorida $\left(\mathrm{C}_{2} \mathrm{H}_{4} \mathrm{C}_{12}\right)$. Senyawa ini dapat mengikat residu $\mathrm{Pb}$ yang dihasilkan setelah pembakaran, sehingga di dalam gas buangan terdapat senyawa $\mathrm{Pb}$ dengan halogen.

Bahan aditive yang biasa dimasukkan ke dalam bahan bakar kendaraan bermotor pada umumnya terdiri dari $62 \%$ tetraetil-Pb, $18 \%$ etilendikhlorida, $18 \%$ etilenbromida dan sekitar 2\% campuran tambahan dari bahan - bahan yang lain. Jumlah senyawa $\mathrm{Pb}$ yang jauh lebih besar dibandingkan dengan senyawa - senyawa lain dan tidak terbakar musnahnya $\mathrm{Pb}$ dalam peristiwa pembakaran pada mesin menyebabkan jumlah $\mathrm{Pb}$ yang dibuang ke udara melalui asap asap buangan kendaraan bermotor menjadi sangat tinggi. Berdasarkan pada analisis yang pernah dilakukan, dapat diketahui kandungan bermacam - macam senyawa $\mathrm{Pb}$ yang ada dalam asap kendaraan bermotor padda tabel berikut :

Tabel5.1 Kandungan senyawa $\mathrm{Pb}$ dalam gas buangan kendaraan bermotor

\begin{tabular}{lcc}
\hline $\begin{array}{c}\text { Senyawa Pb } \\
\text { (\%) }\end{array}$ & 0 Jam & 18 Jam \\
\hline $\mathrm{PbBrCl}$ & 32,0 & 12,0 \\
\hline $\mathrm{PbBrCl} .2 \mathrm{PbO}$ & 31,4 & 1,6 \\
\hline $\mathrm{PbCl} 2$ & 10,7 & 8,3 \\
\hline $\mathrm{Pb}(\mathrm{OH}) \mathrm{Cl}$ & 7,7 & 7,2 \\
\hline $\mathrm{PbBr} 2$ & 5,5 & 0,5 \\
\hline $\mathrm{PbCl}{ }^{2} .2 \mathrm{PbO}$ & 5,2 & 5,6 \\
\hline $\mathrm{Pb}(\mathrm{OH}) \mathrm{Br}$ & 2,2 & 0,1 \\
\hline $\mathrm{PbOx}$ & 2,2 & 21,2 \\
\hline $\mathrm{PbCO}^{3}$ & 1,2 & 13,8 \\
\hline $\mathrm{PbBr}^{2} .2 \mathrm{PbO}$ & 1,1 & 0,1 \\
\hline $\mathrm{PbCO}^{3} .2 \mathrm{PbO}$ & 1,0 & 29,6 \\
\hline
\end{tabular}

Sebagian besar dari Timbal (Pb) yang terhirup pada saat bernafas akan masuk ke dalam pembuluuh darah paru - paru. Tingkat penyerapan itu sangat dipengaruhi oleh ukuran partikel Timbal $(\mathrm{Pb})$ yang ada dan volume udara yang mampu dihirup pada saat peristiwa bernafas berlangsung. Makin kecil ukuran partikel debu, maka akan semakin besar pula konsentrasi Timbal (Pb) yang diserap oleh tubuh. Logam Timbal $(\mathrm{Pb})$ yang masuk ke paru paru melalui peristiwa pernafasan akan terserap dan berikatan dengan darah paru - paru untuk kemudian diedarkan ke seluruh jaringan dan organ tubuh (Heryando Palar, 2004 - h.83).

Pada jaringan dan/atau organ tubuh, logam Timbal (Pb) akan terakumulasi pada tulang, karena logam ini dalam bentuk ion $\left(\mathrm{Pb}^{2+}\right)$ mampu menggantikan keberadaan ion $\mathrm{Ca}^{2+}$ (kalsium) yang terdapat dalam jaringan tulang. Disamping itu, pada wanita hamil logam $\mathrm{Pb}$ dapat melewati plasenta dan kemudian akan ikut masuk dalam sistem peredaran darah darah janin dan selanjutnya setelah bayi lahir, $\mathrm{Pb}$ akan dikeluarkan bersama air susu (Heryando Palar, 2004 - h.83).

3. Kondisi Lingkungan

Menurut Heryando Palar (2004) Jumlah Pb di udara mengalami peningkatan yang sangat drastis sejak dimulainya revolusi industri di Benua Eropa. Asap yang berasal dari cerobong pabrik sampai pada kenalpot kendaraan telah melepaskan $\mathrm{Pb}$ ke udara. Hal ini berlangsung terus menerus sepanjang hari, sehingga kandungan $\mathrm{Pb}$ di udara naik secara sangat mencolok sekali. Kenyataan ini secara dramatis dibuktikan dengan suatu hasil penelitian terhadap kandungan $\mathrm{Pb}$ yang terdapat pada lapisan es di Greenland pada tahun 1969.

Arus angin ternyata telah menerbangkan debu - debu dan partikulat - partikulat yang mengandung logam $\mathrm{Pb}$ ke daerah kutub. Debu dan partikulat tersebut menumpuk pada lapisan atmosfir di kutub, dan kemudian dibawa turun oleh salju untuk selanjutnya membentuk lapisan es. Sampel - sampel yang diambil pada kedalaman tertentu pada lapisan es di Greenland, dimana setiap lapisan mewakili umur sampel yang juga berati merupakan umur dari endapan logam $\mathrm{Pb}$ pada daerah tersebut. Dari penelitian tersebut diketahui bahwa kandungan $\mathrm{Pb}$ mulai mengalami peningkatan setelah revolusi industri, yaitu sekitar abad ke - 18 .

Berdasarkan dari hasil pengamatan kondisi lingkungan di Desa Purbayasa yang meliputi curah hujan dan arah angin selama bulan Maret 2016, Intensitas hujan yang turun di wilayah Purbayasa terjadi setiap sore hingga malam hari. Pada siang hari cuaca cenderung panas dan terik dengan suhu udara $28^{\circ} \mathrm{C}$. Arah angin pada pagi hingga siang hari cenderung ke arah utara namun pada sore hari arah angin menuju ke arah selatan.

Dalam lapisan udara tetraetil-Pb terurai dengan cepat karena adanya sinar matahari. Tetraetil-Pb akan terurai membentuk trietil-Pb, dietil-Pb dan monoetil-Pb. Senyawa - senyawa $\mathrm{Pb}$ dalam keadaan kering dapat terdispersi di dalam udara, sehingga terhirup pada saat bernafas,dan sebagian akan menumpuk di kulit dan/atau terserap oleh daun tumbuhan (Heryando Palar, 2004-h.80). Selain itu hujan dapat menyerap pencemar gas tertentu kedalam partikel air, serta dapat menangkap partikel debu yang mengandung $\mathrm{Pb}$ maupun partikel debu yang lain, menempel pada partikel air dan di bawa jatuh ke bumi. Dengan demikian pencemar 
dalam bentuk partikel akan menempel pada tanaman kangkung (Juniadi, 2012 ).

Sementara itu dari hasil pengamatan untuk arah angin lebih cenderung ke arah utara lebih tepatnya ke arah titik pertama pengambilan sampel (KM 2).

4. Pengelolaan Tanaman Kangkung

Tanaman kangkung merupakan tumbuhan air yang biasanya mempunyai umur sekitar satu tahun atau lebih. Tanaman kangkung akan dipanen pertama kali pada umur satu bulan penanaman. Setelah dipanen kangkung akan dibiarkan tumbuh dan selanjutnya akan dipanen setelah 14 hingga 21 hari, dan biasanaya akan disemprot menggunakan pestisida pada pada umur 10 hari yang dilakukan pada pagi hari. Petani kangkung pada titik pertama (KM 2) menggunakan pestisida dengan merek dagang buldog sedangkan untuk petani titik kedua (KM 3) tidak menggunakan pestisida.

Pestisida diduga dapat mencemari tanaman kangkung karena mengandung Timbal (Pb). Logam berat tersebut akan diserap melalui akar dan stomata daun dan selanjutnya terserap ke dalam jaringan tanaman. Apabila makanan tersebut dimakan oleh makhluk hidup lain, termasuk manusia, maka terjadilah proses biomagnifasi melalui rantai makanan (Alsuhendra dan Ridawati, 2013 h.135).

Berdasarkan penelitian yang dilakukan oleh Eko Hartini dalam Jurnal Visikes (2011) diketahui bahwa umbi bawang merah yang dihasilkan oleh tanah pertanian di Kecamatan Kersana Kabupaten Brebes semuanya mengandung logam berat $\mathrm{Pb}$ dan dalam batas yang cenderung kurang aman karena mendekati batas kritis (kriteria Ditjen POM Departemen Kesehatan adalah 0,2 ppm) dengan hasil rata rata $0,18 \mathrm{ppm}$.

Hasil penelitian Karyadi ( dalam Eko Hartini, 2011 h.70 ) tentang akumulasi logam berat $\mathrm{Pb}$ sebagai residu pada lahan pertanian, studi kasus pada lahan pertanian bawang merah di Kecamtan Gemuh, Kabupaten Kendal, berdasarkan hasil pemeriksaan oleh Balai Penelitian dan Pengembangan Industri Semarang, diektahui bahwa pada beberapa pestisida mengandung logam berat $\mathrm{Pb}$ diantaranya adalah Buldog 25 EC. Indikasi kemungkinan adanya $\mathrm{Pb}$ di dalam pestisida diduga pada bahan pestisida itu sendiri dimungkinkan mengandung logam berat $\mathrm{Pb}$, karena bahan baku pestisida berasal dari pengeboran minyak bumi. Pestisida cair dibuat dengan melarutkan bahan aktif dengan pelarut xylene, naftalen dan karosen. Formulasi pestisida dalam bentuk padat dibuat dari bahan aktif dihaluskan kemudian dicampur dengan bahan pewarna inert misal tepung kaolin, pasir, kapur dan tanah liat. Bahan - bahan yang berasal dari minyak bumi, pelarut dengan menggunakan kerosen atau minyak tanah merupakan hasil penyulingan minyak mentah dan zat pembawa misal kaolin, kapur, pasir dan tanah liat yang dicampurkan dalam formulasi pestisida, dimungkinkan mengandung logam berat $\mathrm{Pb}$.

Umur pada kangkung juga mempengaruhi terhadap adanya kandungan timbal pada tanaman itu sendiri. Pada titik pertama (KM 2) kangkung berumur 9 bulan dan titik kedua (KM 3) kangkung berumur 6 bulan, tanaman kangkung pada titik pertama kadar timbalnya lebih besar dari titik kedua. Hal ini diduga karena semakin lama umur kangkung maka semakin banyak logam berat yang berada disekitarnya yang diserap melalui akar dan stomata.

\section{IV.SIMPULAN DAN SARAN}

\section{Simpulan}

1. Kangkung yang ditanam di sepanjang jalan Raya Purbayasa sudah terpapar oleh timbal (Pb), kadar timbal $(\mathrm{Pb})$ pada kangkung pada titik pertama (KM 2) sebesar $0,053 \mathrm{mg} / \mathrm{kg}$ bb dan titik kedua (KM 3) sebesar 0,032 mg/kg bb, tetapi kangkung tersebut masih aman untuk dikonsumsi karena kadar timbalnya masih di bawah nilai ambang batas.

2. Kepadatan kendaraan pada kedua titik tersebut dikategorikan arus stabil pada sepeda motor dan arus bebas pada mobil.

3. Kondisi lingkungan disekitar lokasi penanaman kangkung pada saat penelitian dengan curah hujan terjadi hampir setiap hari, arah angin menuju ke arah utara dengan suhu rata - rata 28$30^{\circ} \mathrm{C}$.

4. Pengelolaan tanaman kangkung pada titik pertama (KM 2) menggunakan pestisida dengan merek dagang buldog sementara untuk titik kedua (KM 3) tidak menggunakan pestisida.

\section{Saran}

1. Digalakan program penanaman pohon perindang di sepanjang jalan raya dengan tujuan selain sebagai penyejuk lingkungan juga sebagai filter untuk mengurangi pencemaran oleh gas buang sisa pembakaran bahan bakar kendaraan bermotor.

2. Sebaiknya pada saat akan memasak kangkung cucilah terlebih dahulu secara berulang dengan air yang mengalir sampai bersih, dengan tujuan agar Timbal $(\mathrm{Pb})$ yang menempel pada kangkung akan ikut terbawa air.

3. Bagi para petani sebaiknya mengurangi penggunaan pestisida yang berbahaya atau lebih baik menggunakan pestisida organik.

\section{DAFTAR PUSTAKA}


Alsuhendra dan Ridawati, 2013, Bahan Toksik Dalam Makanan, Bandung : Pt Remaja Rosdakarya

Badan Standarisasi Nasional.2009.SNI 7387:2009 Batas Maksimum Cemaran Logam Berat Dalam Pangan. Badan Satandarisasi Nasional, Jakarta

Eko Hartini, 2011, Kadar Plumbum (Pb) Dalam Umbi Bawang Merah Di Kecamatan Kersana Kabupaten Brebes, Fakultas Kesehatan Universitas Dian Nuswantoro Semarang

F.G. Winarno, 1994, Bahan Tambahan Untuk Makanan Dan Kontaminan, Jakarta : Pustaka Sinar Harapan

Heryando Palar, 2004, Pencemaran Dan Toksikologi Logam Berat, Jakarta : Pt Rineka Cipta

I Made E.Adnyana, 1985, Pemberantasan Serangga Penyebar Penyakit Tanaman Liar Dan Penggunaan Pestisida, Denpasar, Departemen Kesehatan

Mukono, 2000, Prinsip Dasar Kesehatan Lingkungan, Surabaya : Airlangga University Press

Mulastin, 2013, Dampak Pengendalian Hama Dan Penyakit Dengan Pestisida Pada Tanaman Cabai Merah Terhadap Kandungan Logam Timbal (Pb) Dalam Darah Petani, Akademi Kebidanan Al-Hikmah Jepara

Pravimatika Nur Alvy Kusuma Mulyadi, 2015, Studi Kandungan Logam Timbal (Pb) Pada Kerang Kepah (Polymesoda Erosa) Di Tpi (Tempat Pelelangan Ikan) Tanjung Intan Kabupaten Cilacap Tahun 2015, Poltekkes Kemenkes Semarang

Rahmat Rukmana, 1994, Kangkung, Yogyakarta : Penerbit Kansius
Rianawati, 2010, Studi Kadar Timah Hitam (Pb) Pada Tanaman Angsana (Pterocarpus Indicus) Di Jalan Gerliya Purwokerto Tahun 2010, Poltekkes Kemenkes Semarang

Soedjono,Dkk, 1990, Pedoman Bidang Studi Pengawasan Pencemaran Lingkungan Fisik Pada Institusi Pendidikan Tenaga Kesehatan Lingkungan, Jakarta : Departemen Kesehatan RI

Sri Rizqi, 2014, Studi Kadar Timbal Pada Makanan Jajanan Dan Kondisi Sanitasi Pada Pedagang Kaki Lima Di Jalan H.R Bunyamin Purwokerto Utara Tahun 2014, Poltekkes Kemenkes Semarang

Tri Cahyono, 2014, Pedoman Penulisan Proposal Penelitian Dan Karya Tulis Ilmiah, Purwokerto, Jurusan Kesehatan Lingkungan

Tri Dewi Kristini, 1995, Studi Tentang Jarak Tanaman Dengan Sumbu Jalan Terhadap Kadar Pb Pada Kacang Panjang (Vigna Sinensis) Di Desa Bandungan Kecamatan Ambarawa Kabupaten Dati II Semaran, Jurusan Kesehatan Lingkungan Purwokerto

Undang - Undang No. 23 Tahun 1997 Tentang Pengelolaan Lingkungan Hidup

Undang - undang Nomor 22 Tahun 2009 tentang Lalu Lintas Dan Angkutan Jalan

Undang - undang Nomor 36 Tahun 2009 tentang Kesehatan

Undang - undang No 12 Tahun 2012 tentang Pangan

Universitas Sumatera Utara, 2013, Pencemaran Udara, http://repository.usu,ac.id/bitstream/ 123456789/39730/4/Chapter\%20II.pdf diakses tanggal 28 Januari 2016 pukul 23.00

Yati Supriati,Dkk, 2010, Bertanam 15 Sayuran Organik Dalam Pot, Jakarta : Penebar Swadaya 